\title{
STUDY OF BIOCHEMICAL COMPOUNDS AND ANTIMICROBIAL ACTIVITY OF PLEUROTUS INDICA MUSHROOM
}

\author{
O.N.Shanmugapriya and S.Priya*
}

P.G and Research Department of Microbiology, S.T.E.T. Women's College, Mannargudi, T.Nadu, India

P.G Department of Biotechnology, S.T.E.T. Women's College, Mannargudi, T.Nadu, India

Corresponding Author: piri_333@yahoo.co.in, +91 9787392903

\section{ABSTRACT}

In this study, the nutritional values of dietary mushrooms-Pleurotus indica that are very popular among the cultivated mushrooms in India have been determined. P.indica is widely cultivated as it is rich in nutrients and its component. $P$.indica is useful in biomass production in commercial level as it contains proteins and minerals. In this study the value added biochemical compounds in P.indica were analyzed from cultures. The amount of total carotenoids, protein, vitamin, pigments and phenolic compounds were examined. P.indica extracts possessed great potential antibacterial activities against four bacterial strains with inhibition zones ranged $8-15 \mathrm{~mm}$ and MICs values ranges from $25-404 \mathrm{~g} / \mathrm{mL}$. Thus, it could be suggested that the P.indica is useful biosystem for production of biochemical compounds possess an antimicrobial principles.

\section{Indexing terms/Keywords}

P.indica; Biochemical compounds; Culture media; Organic extract.

\section{Council for Innovative Research}

Peer Review Research Publishing System

Journal of Advances in Natural Sciences

Vol 2, No. 2

editorjansonline@gmail.com

www.cirworld.com 


\section{INTRODUCTION}

Mushroom have been a widely used as food and food supplements for millennia. It is an important food item concerning human health, nutrition and disease prevention. There is a common saying that "medicines and foods have a common origin" (Kaul, 2001). Dietary mushrooms provide a wide variety of medicinal properties and they are effective against certain life threatening diseases. Major medicinal properties attributed to mushrooms include anticancer, antibiotic, antiviral activities, immunity and blood lipid lowering effects. Pleurotus spp. is also rich in medicinal values.

This Mushroom are very effective in reducing the total plasma cholesterol and triglyceride level (Nuhu Alam et al., 2007) and thus reduce the chance of atherosclerosis and other cardiovascular and artery related disorders. These medicinal properties might be due to the presence of some important substance in dietary mushrooms. Mushrooms are rich in protein, minerals and vitamins and they contain an abundance of essential amino acids (Sadler, 2003). Nutritional analysis of several mushroom species of different origins had been carried out in many laboratories in the world. But nutritional values of locally cultivated mushrooms remain speculative. Moreover, nutritional composition is affected by many factors; these include differences among strains, the composition of growth substrate, the method of cultivation, stage of harvesting, specific portion of the fruiting bodies used for analysis (Benjamin, 1995). The aim of this investigation was to analyze the nutritional values of these mushrooms cultivated, with a goal of increasing awareness of the beneficial effects of edible mushrooms among the consumers.

\section{MATERIALS AND METHODS}

The wood rotting fungal species of Pleurotus indica was collected from Tamilnadi Argicultural University (TNAU), Coimbatore, India. Fruiting bodies were dried and specimen deposited in Research laboratory, Trichy. The fresh culture of P.indica was obtained by tissue culture technique (Ruhul Amin et al., 2007).

\section{Extraction of bioactive compounds from fruiting bodies of $P$.indica}

The mushroom material was grounded to a fine powder with the help of pestle and mortar. Ten gram of mushroom powder was subjected to Soxhlet extraction using micro Kjeldahl apparatus (ASGI, India) for 10 hours using $100 \mathrm{ml}$ each of the following solvents viz., ethyl alcohol, methanol, acetone and distilled water. The extracts were recovered by filtration and kept at 400C for further analysis (Raghuramulu et al., 2003). All the solvent extracted fractions were subjected to in vacuo desiccation at $40^{\circ} \mathrm{C}$ in a rotary vacuum evaporator to remove any traces of solvents and to obtain residues. The test residues were prepared as stocks using distilled water $(40 \mu \mathrm{g} / \mathrm{ml})$ and were tested for their antibacterial activity.

\section{Antibacterial activity}

Bacterial strains used for the antibacterial evaluation are Bacillus subtilis, Staphylococcus aureus, Micrococcus luteus and Klebsiella pnemoniae. The antibacterial activity was evaluated with the paper disc diffusion method. The minimum inhibitory concentration tests were carried out according the method. MIC was defined as the lowest algal extracts concentrations showing no visible bacterial growth after incubation for $24 \mathrm{~h}$ at $37^{\circ} \mathrm{C}$.

\section{RESULTS AND DISCUSSION}

Analysis of the nutritive value of P.indica in Table-1 shows the influence of concentration on the growth and concentration of total carotenoids, chlorophyll, D-tocopherol, total phenol compounds, proteins and total phycocyanin. The highest concentration of carotenoid content was obtained in culture grown at lowest $(0.25 \mathrm{~g} / \mathrm{L}-1)$ with value of 15.20 mg-1. In contrast, the total chlorophyll and D-tocopherol content was found in culture grown highest at $(1.80 \mathrm{gL}-1)$ with value of 14.35 and $1.32 \mathrm{mg}-1$.

Both vitamin- $C$ and total protein maximum content were obtained with values of 3.98 and 8.25 mg- 1.Thus the highest concentration of phycocyanin with value of 55.70 and the highest phenol content at $6.55 \mathrm{gL}-1$. This findings might explain (Crisan and Sands, 1978) with that the $\mathrm{Nacl}_{2}$ is grown cells under higher $\mathrm{Nacl}_{2}$ level required for synthesis of the amino acids, which makeup proteins and other cellular components such as chlorophylls and phycocyanin. However, higher concentration of $\mathrm{Nacl}_{2}$ led to an increase level of biochemical compounds.

The antibacterial of $P$.indica extracts were assayed against for bacterial strains Bacillus subtilis, Staphylococcus aureus, Micrococcus luteus and Klebsiella pnemoniae by evaluating the inhibition zones, zone diameter and MIC values. Generally, all P.indica extracts were found to be effective against all tested bacteria and the antibacterial activities was found to be dose dependent. The data in table-2 showed that the most susceptible bacteria were Klebsiella pnemoniae and Staphylococcus aureus to the organic extracts with highest inhibition zone ranged 4-9 mg/disc. It is of interest to note that all P.indica organic extracts manifested similar degrees of susceptibility towards both gram positive and negative bacteria.

On the other hand, P.indica extracts showed good potential of antibacterial activities against all of four bacteria with MICs ranged from $30-40 \mu \mathrm{g} / \mathrm{mL}$. The maximal inhibition zones and MIC values for bacterial strains sensitive to 
chloramphenicol as a standard antibiotic were in ranged of $13-20 \mathrm{~mm}$ and $20 \mu \mathrm{g} \mathrm{mL}-1$ and with those published (Dundar et al., 2008) mentioned that the antibacterial effect of biochemical compounds are in concentration dependent.

In conclusion, the chemical composition of edible mushrooms determines their nutritional value and sensory properties as also mentioned by other authors (Shah et al., 1997; Manzi et al., 2001). They differ according to species but this difference also depends on the substratum, atmospheric conditions, age and part of the fructification. We found different nutritional values in the different part of cultivated mushrooms. These data suggest that dietary mushrooms cultivated are good source of nutrients specially protein and fiber. Mushrooms are rich in protein, edible fiber and minerals but lipid content is low. These results also indicate that the studied mushrooms have good nutritive value for human. Protein is an important nutritional component and protein deficiency is the world's most serious human nutritional problem, especially in third world countries like India. So mushroom is a promising food that may overcome protein-energy malnutrition problem in the third world.

\section{REFERENCES}

1. Kaul T.N., 2001. Biology and Conservation of Mushrooms. New Delhi, India: Oxford \& IBH Publishing Co. Pvt. Ltd; 117-145.

2.Nuhu Alam, Hossain Shahdat, Khair Abul, Amin Ruhul, Asaduzzaman K.,2007. Comparative effects of oyster mushrooms on plasma lipid profile of hypercholesterolaemic rats. Bangladesh J Mushroom. 1:15-22.

165.

3.Benjamin D.R.,1995. Mushroom, Poisons and Panaceas. New York, USA: W. H. Freeman \& Company;151-

4.Sadler M.,2003. Nutritional properties of edible fungi. Br Nutr Found Nutr Bull., 28:305-308.

5.Amin Ruhul, Nirod C.S., Mahbuba M., Jebunnahar K., Rahman Mahfuzur. 2007. Officer's Training Manual. Savar, Dhaka, Bangladesh: National Mushroom Development and Extension Centre.13-17.

6.Raghuramulu N., Madhavan N.K., Kalyanasundaram S., 2003. A Manual of Laboratory Techniques. Hyderabad, India: National Institute of Nutrition. Indian Council of Medical Research. 56-58.

7. Crisan E.V., Sands A., 1978. Nutritional value. In: Chang ST, Hayes WA, editors. The biology and cultivation of edible mushrooms. U.S.A.: New York Academic Press; 137-165.

8.Shah H., lqtidar A.K., Shagufta J.,1997. Nutritional composition and protein quality of Pleurotus mushroom.Sarhad J Agric., 13:621-626.

9.Manzi P., Aguzzi A., Pizzoferrato L.,2001. Nutritional value of mushrooms widely consumed in Italy. Food Chem., 73:321-325.

10. Dundar A., Acy H., Yildiz A.,2008. Yield performance and nutritional contents of three oyster mushroom species cultivated on wheat stalk. Afr J Biotech., 7:3497-3501. 
Table-1: Levels of biochemical compounds found in P.indica

\begin{tabular}{|l|l|l|l|l|l|l|}
\hline Chlorophyll & Carotenoids & Phenol & Tocopherol & Protein & Phycocyanin & Vit-C \\
\hline $12.23 \pm 24$ & $7.32 \pm 0.46$ & $3.98 \pm 00$ & $0.26 \pm 0.04$ & $8.25 \pm .00$ & $30 \pm 1.14$ & $3.55 \pm 70$ \\
\hline $14.35 \pm 1.2$ & $8.25 \pm 0.35$ & $4.23 \pm 0.21$ & $1.32 \pm 0.05$ & $3.90 \pm .70$ & $40 \pm 1.40$ & $3.00 \pm 10$ \\
\hline $12.63 \pm 1.1$ & $12.3 \pm 0.94$ & $6.55 \pm 0.27$ & $0.50 \pm 0.03$ & $4.50 \pm .00$ & $45 \pm 1.23$ & $2.10 \pm 40$ \\
& & & & & & \\
\hline $8.12 \pm 0.9$ & $15.2 \pm 0.98$ & $3.22 \pm 0.25$ & $0.40 \pm 0.00$ & $5.85 \pm .99$ & $55 \pm 1.13$ & $1.00 \pm 50$ \\
\hline
\end{tabular}

Values are significant at $\mathrm{P}=0.01$

Table-2: Antibacterial activity and MIC of P.indica

\begin{tabular}{|c|c|c|c|c|c|c|c|c|c|c|c|c|}
\hline \multirow[t]{2}{*}{ Bacterial strain } & \multicolumn{3}{|c|}{$\begin{array}{l}(\mu \mathrm{g}) \text { grown in } \\
2.15 \mathrm{gL}-1\end{array}$} & \multicolumn{3}{|c|}{$\begin{array}{l}(\mu \mathrm{g}) \text { grown in } \\
1.80 \mathrm{gL}-1\end{array}$} & \multicolumn{3}{|c|}{$\begin{array}{l}(\mu \mathrm{g}) \text { grown in } \\
1.50 \mathrm{gL}-1\end{array}$} & \multicolumn{3}{|c|}{$\begin{array}{l}(\mu \mathrm{g}) \text { grown in } \\
0.25 \mathrm{gL}-1\end{array}$} \\
\hline & Disc & $\mathbf{A b}$ & MIC & Disc & $\mathbf{A b}$ & MIC & Disc & $\mathbf{A b}$ & MIC & D & & \\
\hline S.aureus & 15 & 21 & 20 & 7 & 8 & 40 & 9 & 12 & 30 & 5 & 10 & 25 \\
\hline B.subtilis & 16 & 22 & 20 & 4 & 7 & 40 & 8 & 10 & 30 & 4 & 09 & 25 \\
\hline M.luteus & 14 & 19 & 20 & 4 & 6 & 40 & 8 & 11 & 30 & 4 & 07 & 25 \\
\hline K.pnemoniae & 18 & 23 & 23 & 5 & 6 & 40 & 8 & 11 & 30 & 4 & 07 & 25 \\
\hline
\end{tabular}

